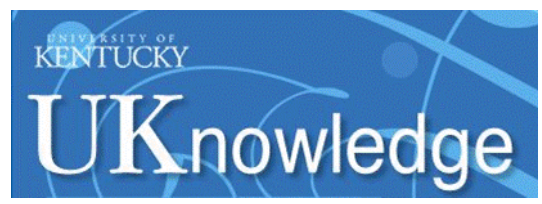

University of Kentucky

UKnowledge

Comparative Proteomic Analyses of the Parietal Lobe from Rhesus Monkeys Fed a High-Fat/Sugar Diet With and Without Resveratrol Supplementation, Relative to a Healthy Diet: Insights Into the Roles of Unhealthy Diets and Resveratrol on Function

\author{
Aaron M. Swomley \\ University of Kentucky, aaron.swomley@uky.edu \\ Judy C. Triplett \\ University of Kentucky, jctriple3883@yahoo.com \\ Jeriel T. Keeney \\ University of Kentucky, jtke224@uky.edu \\ Govind Warrier \\ University of Kentucky \\ KeYYoW thPsear\$\$Qdditional works at: https://uknowledge.uky.edu/chemistry_facpub \\ IIniversity of Kentucky, kevin.pearson@uky.edu \\ Part of the Biochemistry Commons, Chemistry Commons, and the Nutrition Commons \\ Right click to open a feedback form in a new tab to let us know how this document benefits you. \\ See next page for additional authors

\section{Repository Citation} \\ Swomley, Aaron M.; Triplett, Judy C.; Keeney, Jeriel T.; Warrier, Govind; Pearson, Kevin J.; Mattison, Julie \\ A.; de Cabo, Rafael; Cai, Jian; Klein, Jon B.; and Butterfield, D. Allan, "Comparative Proteomic Analyses of \\ the Parietal Lobe from Rhesus Monkeys Fed a High-Fat/Sugar Diet With and Without Resveratrol \\ Supplementation, Relative to a Healthy Diet: Insights Into the Roles of Unhealthy Diets and Resveratrol on \\ Function" (2017). Chemistry Faculty Publications. 150. \\ https://uknowledge.uky.edu/chemistry_facpub/150
}

This Article is brought to you for free and open access by the Chemistry at UKnowledge. It has been accepted for inclusion in Chemistry Faculty Publications by an authorized administrator of UKnowledge. For more information, please contact UKnowledge@lsv.uky.edu. 
Comparative Proteomic Analyses of the Parietal Lobe from Rhesus Monkeys Fed a High-Fat/Sugar Diet With and Without Resveratrol Supplementation, Relative to a Healthy Diet: Insights Into the Roles of Unhealthy Diets and Resveratrol on Function

Digital Object Identifier (DOI)

https://doi.org/10.1016/j.jnutbio.2016.10.006

Notes/Citation Information

Published in The Journal of Nutritional Biochemistry, v. 39, p. 169-179.

(c) 2016 Elsevier Inc. All rights reserved.

This manuscript version is made available under the CC-BY-NC-ND 4.0 license

https://creativecommons.org/licenses/by-nc-nd/4.0/.

The document available for download is the author's post-peer-review final draft of the article.

Authors

Aaron M. Swomley, Judy C. Triplett, Jeriel T. Keeney, Govind Warrier, Kevin J. Pearson, Julie A. Mattison, Rafael de Cabo, Jian Cai, Jon B. Klein, and D. Allan Butterfield

This article is available at UKnowledge: https://uknowledge.uky.edu/chemistry_facpub/150 
J Nutr Biochem. 2017 January ; 39: 169-179. doi:10.1016/j.jnutbio.2016.10.006.

\title{
Comparative proteomic analyses of the parietal lobe from rhesus monkeys fed a high-fat/sugar diet with and without resveratrol supplementation, relative to a healthy diet: Insights into the roles of unhealthy diets and resveratrol on function
}

\author{
Aaron M. Swomley ${ }^{\mathrm{a}, \mathrm{c}, 1}$, Judy C. Triplett ${ }^{\mathrm{a}, \mathrm{c}, 1}$, Jeriel T. Keeney ${ }^{\mathrm{a}}$, Govind Warrier ${ }^{\mathrm{a}}$, Kevin J. \\ Pearson $^{\mathrm{c}, \mathrm{d}}$, Julie A. Mattison ${ }^{\mathrm{e}}$, Rafael de Cabo $^{\mathrm{e}}$, Jian Cai ${ }^{\mathrm{b}}$, Jon B. Klein ${ }^{\mathrm{b}}$, and D. Allan \\ Butterfield ${ }^{a, c},{ }^{*}$ \\ aDepartment of Chemistry, University of Kentucky, Lexington, KY 40536, USA \\ bProteomics Center, University of Louisville, Louisville, KY 40202, USA \\ 'Sanders-Brown Center on Aging, University of Kentucky, Lexington, KY 40536, USA \\ dMolecular and Biomedical Pharmacology and Nutrition, University of Kentucky, Lexington, KY \\ 40536, USA \\ eTranslational Gerontology Branch, National Institute on Aging, NIH, Baltimore, MD 21224, USA
}

\begin{abstract}
A diet consisting of a high intake of saturated fat and refined sugars is characteristic of a Westerndiet and has been shown to have a substantial negative effect on human health. Expression proteomics were used to investigate changes to the parietal lobe proteome of rhesus monkeys consuming either a high fat and sugar (HFS) diet, a HFS diet supplemented with resveratrol (HFS +RSV), or a healthy control diet for 2 years. Here we discuss the modifications in the levels of 12 specific proteins involved in various cellular systems including metabolism, neurotransmission, structural integrity, and general cellular signaling following a nutritional intervention. Our results contribute to a better understanding of the mechanisms by which resveratrol functions through the up- or down-regulation of proteins in different cellular sub-systems to affect the overall health of the brain.
\end{abstract}

\section{Keywords}

Resveratrol; Proteomics; Western diet; Rhesus monkey; Brain

\section{Introduction}

The Western diet has been under much scrutiny in the past couple of decades due to the abundance of saturated fat and refined sugar (HFS) content commonly used in food

*Corresponding author at: Department of Chemistry and Sanders-Brown Center on Aging, University of Kentucky, Lexington, KY 40506-0055. Tel.: +1 859257 3184; fax: +1 859323 1464. dabcns@ @ky.edu (D.A. Butterfield).

${ }^{1}$ Both authors contributed equally to this study. 
preparation. Long term consumption of HFS has been linked to a number of physiological conditions such as obesity, insulin resistance and type-2 diabetes mellitus, cardiac disease, ischemia, cancer, and cognitive dysfunction [1]. The projected costs of obesity-related diseases are measured not only in monetary terms, but also in life-years used to treat the disease and life-years lost to early death associated with obesity and unhealthy diets in general.

Resveratrol (RSV) is a polyphenol found primarily in red grapes, blueberries, cranberries, nuts such as peanuts and pistachios, as well as in cocoa. RSV has garnered widespread acclaim due to the many studies linking it to beneficial effects such as neuroprotection, antiinflammation, regulation of metabolic pathways, improved glucose tolerance, and as an antioxidant [2-5]. The mode of action for RSV appears to be its indirect activation of the $\mathrm{NAD}^{+}$-dependent deacetylase, sirtuin-1 (SIRT1),possibly through the inhibition of cyclic AMP (cAMP)-degrading phosphodiesterase, that leads to the deacetylation of the p65 subunit of NF- $\kappa \mathrm{B}[6-9]$.

The parietal lobe of the brain is primarily responsible for the integration of sensory information, both tactile and perceived, as well as spatial recognition and processing of both language and memory. Impairments to the parietal lobe are seen in a number of neurodegerative diseases such as Alzheimer disease (AD), Parkinson disease, and amyotrophic lateral sclerosis [10-12]. AD in particular, along with its earlier stage, amnestic-mild cognitive impairment (aMCI), have been linked to proteome dysfunction in most regions of the brain, including parietal lobule, indicating that a healthy and functioning proteome is necessary for normal brain function $[13,14]$. Although there has been considerable research on the effects of RSV in a number of scenarios and models, a proteomic analysis of the primate brain has yet to be conducted. With 95\% genetic homology, rhesus monkeys are an ideal translational model toward understanding the effects of a Westernized diet and the influence of RSV supplementation in a primate brain, modeling humans. Through the use of discovery-based proteomics methodology, the current study led to the identification of parietal proteins important in energy production, cellular signaling, and neurotransmission within the proteome of rhesus monkey parietal lobe which might play a role in neurodegenerative disease or dysfunction associated with an unhealthy diet.

\section{Materials}

The chemicals used in these experiments were purchased from Sigma-Aldrich (St. Louis, MO, USA) with the following exceptions: Criterion precast polyacrylamide gels, ReadyStrip ${ }^{\mathrm{TM}}$ IPG strips (pH 3-10), Precision Plus Protein ${ }^{\mathrm{TM}}$ All Blue Standards, Sypro Ruby Protein Stain, MOPS and TGS running buffers, $0.2 \mathrm{~nm}$ nitrocellulose membrane, mineral oil, dithiothreitol, iodoacetamide, biolytes, and urea were purchased from Bio-Rad (Hercules, CA, USA).Modified trypsin solution was obtained from Promega (Madison, WI, USA) and $\mathrm{C}_{18}$ ZipTips were acquired from Millipore (Billerica, MA, USA). Anti-alphainternexin and anti-chloride intracellular channel protein antibodies were procured from Santa Cruz (Dallas, TX, USA). Amersham ECL IgG horseradish peroxidase-linked secondary antibodies, ECL-Plus Western blotting chemiluminescent detection reagents as 
well as Re-Blot Plus Strong stripping solutions were purchased from GE Healthcare (Pittsburgh, PA, USA).

\subsection{Animals}

Twenty-three adult (7-13 years old) male rhesus monkeys (Macaca mulatta) were housed at the NIH Animal Center, Poolesville, MD, a center fully accredited by the American Association for Accreditation of Laboratory Animal Care. All procedures were approved by the Animal Care and Use Committee of the NIA Intramural Program.

2.1.1. Experimental diet-Monkeys were randomized into one of three groups: a healthy standard diet (Cont, $n=3$ ) or a high fat/high sugar diet in combination with either placebo (HFS, $n=10$ ) or resveratrol (HFS+RSV, $n=10$ ). The Cont diet was a standard purified chow consisting of $13 \%$ of $\mathrm{kcal}$ in fat and $<5 \%$ sucrose by weight (Purina Mills, St. Louis, MO, USA). The HFS diet was a specially formulated purified ingredient diet with $42 \%$ of kcal in fat and approximately $27 \%$ sucrose by weight (Harlan, Teklad, Indianapolis, IN, USA). The monkeys were gradually switched to the HFS diet over a 3-week period. Monkeys received two meals per day at estimated ad libitum levels throughout the study and water was always available. The average food consumption (kcals/day) for weekly periods was the same for all groups.

The RSV dose was derived from the protective dose reported in mice (22 $\mathrm{mg} / \mathrm{kg})$ [15] and adjusted by allometric scaling to an average monkey body weight of $12.1 \mathrm{~kg}$. RSV was supplied by DSM Nutritional Products, Parsippany, NJ. HFS+RSV monkeys received $40 \mathrm{mg}$ RSV twice a day for the first year which was increased to $240 \mathrm{mg}$ twice a day during the second year in order to raise plasma RSV levels. The HFS and Cont monkeys received a placebo treat (Bio-Serv, Frenchtown, NJ, USA). Additional experimental details have been described previously [16-18].

2.1.2. Sacrifice and tissue harvest-Anesthesia was induced with Ketamine (7-10 $\mathrm{mg} / \mathrm{kg}, \mathrm{IM}$ ) and, following blood collection, the monkeys were deeply anesthetized with a lethal dose of sodium pentobarbital (50 mg/kg, IP). Once maximally sedated, the monkeys were perfused with cold lactated Ringer's solution. Tissues were harvested immediately, flash frozen in liquid nitrogen, and stored at $-80{ }^{\circ} \mathrm{C}$ until use.

\subsection{Sample preparation}

The parietal lobules from the brains of rhesus monkeys were thawed at $4{ }^{\circ} \mathrm{C}$ and individual homogenates were prepared with a Wheaton glass homogenizer (approximately 40 passes) with ice-cold isolation buffer [0.32 M sucrose, 2 mM EDTA, 2 mM EGTA, 20 mM HEPES, $0.2 \mu \mathrm{g} / \mathrm{ml}$ PMSF, $4 \mu \mathrm{g} / \mathrm{ml}$ leupeptin, $4 \mu \mathrm{g} / \mathrm{ml}$ pepstatin, $5 \mu \mathrm{g} / \mathrm{ml}$ aprotinin]. Homogenates were thoroughly vortexed and subsequently sonicated on ice for $10 \mathrm{~s}$ at $20 \%$ power, a total of two times, allowing the sample to rest $20 \mathrm{~s}$ on ice between vortexings, with a Fisher 550 Sonic Dismembrator (Pittsburgh, PA, USA). Concentration of the total protein in the homogenates was determined by the Pierce BCA method (Rockford, IL, USA). 


\subsection{Two-dimensional polyacrylamide gel electrophoresis (2-D PAGE)}

2.3.1. Isoelectric focusing (IEF)—Brain tissue homogenates (200 $\mu \mathrm{g})$ were shaken in $200 \mu \mathrm{l}$ of rehydration buffer [8 M urea, 2.0\% (w/v) CHAPS, $2 \mathrm{M}$ thiourea, $50 \mathrm{mM}$ DTT, $0.2 \%$ biolytes, $0.01 \%$ bromophenol blue] for $1.5 \mathrm{~h}$ at RT and then sonicated for $10 \mathrm{~s}$ at $20 \%$ power. Samples were applied to $11 \mathrm{~cm} \mathrm{pH} \mathrm{3-10} \mathrm{ReadyStrip}{ }^{\mathrm{TM}}$ IPG strips with a linear gradient. IPG strips were actively rehydrated at $20{ }^{\circ} \mathrm{C}$ for $18 \mathrm{~h}$ at $50 \mathrm{~V}$ using a Bio-Rad Protean IEF Cell (Hercules, $C A$, USA). After the first $60 \mathrm{~min}, 2 \mathrm{~mL}$ of mineral oil was added to the strips. Next, isoelectric focusing was carried out at a constant temperature of $20^{\circ} \mathrm{C}$ beginning at $300 \mathrm{~V}$ for $2 \mathrm{~h}, 500 \mathrm{~V}$ for $2 \mathrm{~h}, 1000 \mathrm{~V}$ for $2 \mathrm{~h}, 8000 \mathrm{~V}$ for $8 \mathrm{~h}$, and ending at $8000 \mathrm{~V}$ for $10 \mathrm{~h}$. The IPG strips were immediately stored at $-80{ }^{\circ} \mathrm{C}$ until use.

2.3.1.1. SDS page: IPG strips were thawed for $10 \mathrm{~min}$ and then $4 \mathrm{ml}$ of a DTT-containing equilibration buffer [50 mM Tris-HCl, $\mathrm{pH}$ 6.8, $6 \mathrm{M}$ urea, $1 \%$ (w/v) SDS, 30\% v/v glycerol, $0.5 \%$ DTT] was added for $10 \mathrm{~min}$ in the dark. This solution was removed and $4 \mathrm{ml}$ of an iodoacetamide-containing buffer [50 mM Tris-HCl, pH 6.8, $6 \mathrm{M}$ urea, 1\% (w/v) SDS, 30\% $\mathrm{v} / \mathrm{v}$ glycerol, $4.5 \%$ iodoacetemide] for $10 \mathrm{~min}$ in the dark. IPG strips were then rinsed in a $1 \times$ dilution of TGS running buffer and placed into Criterion precast linear gradient (8-16\%) Tris-HCl polyacrylamide gels. Precision Plus Protein ${ }^{\mathrm{TM}}$ All Blue molecular weight marker was added and agarose gel was overlaid. Gels were run at a constant voltage of $200 \mathrm{~V}$ for approximately 65 min until completion using $1 \times$ Tris/Glycine/SDS running buffer.

\subsection{SYPRO ruby staining}

Following 2D-PAGE, gels were fixed in solution [7\% (v/v) acetic acid, 10\% (v/v) methanol] $(50 \mathrm{ml})$ for $45 \mathrm{~min}$ at RT on a gently orbiting platform. Next, the fixing solution was removed and $50 \mathrm{ml}$ of Sypro Ruby Protein Gel Stain was added and stained proteins in the gel overnight $(15 \mathrm{~h})$ at RT with gentle orbiting. Gels were rinsed and transferred to $50 \mathrm{ml}$ of deionized water at RT until scanning. Gels were scanned using a Bio-Rad ChemiDoc XRS+ imaging system (Hercules, CA, USA) and stored in deionized water at $4{ }^{\circ} \mathrm{C}$ until extraction of protein spots.

\subsection{Image analysis}

Spot intensities of the imaged SYPRO Ruby-stained 2D gels were quantified by densitometry using PDQuest 2-D Analysis Software (Bio-Rad, Hercules, CA, USA). Individual gel spot intensities were normalized to the total density of the respective gel. Spot densities from the three sample groups (Cont, HFS, HFS+RSV) were compared and spots with a statistically significant difference based on a Student's two-tailed $t$ test $(P<.05)$ were considered for in-gel trypsin digestion and the subsequent identification of the protein.

\subsection{In-gel trypsin digestion and peptide extraction}

Statistically significant protein spots were excised from 2D-gels and transferred to Eppendorf microcentrifuge tubes. Next, $20 \mu \mathrm{L}$ of $0.1 \mathrm{M}$ ammonium bicarbonate $\left(\mathrm{NH}_{4} \mathrm{HCO}_{3}\right)$ was added to each tube and incubated at RT for $15 \mathrm{~min}$, followed by an addition of $30 \mu \mathrm{L}$ of acetonitrile at RT for $15 \mathrm{~min}$. The solvent was removed and gel plugs dried at RT for approximately $30 \mathrm{~min}$. Then, $30 \mu \mathrm{l}$ of $20 \mathrm{mM}$ DTT in $0.1 \mathrm{M} \mathrm{NH}_{4} \mathrm{HCO}_{3}$ was 
added to the gel plugs and incubated for $45 \mathrm{~min}$ at $56^{\circ} \mathrm{C}$. After removal of the DTT/ $\mathrm{NH}_{4} \mathrm{HCO}_{3}$ solution, $30 \mu \mathrm{l}$ of $0.05 \mathrm{M}$ iodoacetamide (IA) in $0.1 \mathrm{M} \mathrm{NH}_{4} \mathrm{HCO}_{3}$ was added and gel plugs incubated at RT for $15 \mathrm{~min}$. The IA solution was then removed and $150 \mu \mathrm{l}$ of 0.05 $\mathrm{MNH}_{4} \mathrm{HCO}_{3}$ was added to incubate for $15 \mathrm{~min}$ at RT. Next, $200 \mu \mathrm{l}$ of acetonitrile (ACN) was added to this solution and incubated for an additional $15 \mathrm{~min}$. Gel plugs were dried for 30 min at RT before rehydrating with $10 \mu \mathrm{l}$ of modified trypsin solution in $0.05 \mathrm{MNH}_{4} \mathrm{HCO}_{3}$. Plugs were incubated at $37{ }^{\circ} \mathrm{C}$ and shaken at $230 \mathrm{RPMs}$ for $15 \mathrm{~h}$. The digest solution was transferred into a new Eppendorf tube and then $20 \mu \mathrm{l}$ of a $5 \%$ ACN, $0.1 \%$ formic acid (FA) solution was added to the old tube containing the gel plug and sonicated in a bath for 15 min. To this, $30 \mu \mathrm{l}$ of a $95 \% \mathrm{ACN}, 0.1 \% \mathrm{FA}$ and $0.001 \mathrm{M} \mathrm{NH}_{4} \mathrm{CO}_{3}$ solution was added and sonicated for $15 \mathrm{~min}$. The solution was removed from the gel plug tube and combined with the supernatant digest solution. Using a Speedy Vac, the samples were subsequently concentrated to a volume of approximately $10 \mu \mathrm{l}$. Salts and contaminants were removed from the trypsin-digested peptide solution with $\mathrm{C}_{18}$ ZipTips. $10 \mu \mathrm{l}$ of $100 \%$ ACN was aspirated into the tip and expelled a total of 5 times. Next, $10 \mu \mathrm{l}$ of a $50 \%$ ACN solution containing $0.1 \%$ FA was aspirated and ejected a total of 5 times. The trypsin digested solution was then slowly drawn up and pushed gently out of the column a total of 10 times for peptide adherence. The contaminants were eliminated from the peptides in the ZipTip by washing with $10 \mu \mathrm{l}$ of a $5 \% \mathrm{ACN}$ and $0.1 \%$ FA solution a total of 3 times. Peptides were extracted from the column with $10 \mu \mathrm{l}$ of a $50 \%$ ACN and $0.1 \%$ FA solution by slowly drawing up and expelling the eluent a total of 5 times. Samples were stored at $-80{ }^{\circ} \mathrm{C}$ until MS analysis.

\subsection{NanoLC-MS with data dependent scan}

The de-salinated samples were reconstituted in $10 \mu \mathrm{L} 5 \%$ ACN/0.1\% FA and analyzed by a nanoAcquity (Waters, Milford, MA)-LTQ Orbitrap XL (Thermo Scientific, San Jose, CA, USA) system in data dependent scan mode. An in-house packed capillary column $(0.1 \times 130$ mm column packed with $3.6 \mu \mathrm{m}, 200 \AA$ XB-C18) and a gradient with $0.1 \%$ FA and ACN/ $0.1 \% \mathrm{FA}$ at $200 \mathrm{~nL} / \mathrm{min}$ were used for separation. The MS spectra were acquired by the orbitrap at 30,000 resolution and MS/MS spectra of the six most intense ions in MS scan were obtained by the orbitrap at 7500 resolution. Data files from each sample were searched against the most current version of the Swiss-Prot database by SEQUEST (Proteome Discoverer v1.4, Thermo Scientific). A minimum of two high-confidence peptide matches were required for protein identification (false discovery rate $<1 \%$ ). Proteins matched with the same peptides are reported as one protein group. Resultant MS/MS data were initially verified by comparison of the expected molecular weight and isoelectric point of the identified protein to that of the extracted plug from the 2-D gel.

\subsection{1-D western blotting validation}

\subsubsection{One-dimensional polyacrylamide gel electrophoresis (1D-PAGE)-}

Parietal lobule homogenates $(50 \mu \mathrm{g})$ were suspended in $4 \times$ sample loading buffer $[0.5 \mathrm{M}$ Tris, pH 6.8, 40\% glycerol, $8 \%$ SDS, 20\% $\beta$-mercaptoethanol, $0.01 \%$ Bromophenol Blue] diluted to $1 \times$ with distilled water. Samples were then heated at $95{ }^{\circ} \mathrm{C}$ for $5 \mathrm{~min}$, cooled on ice and loaded into a Criterion precast (4-12\%) Bis-Tris polyacrylamide 12 well gel with Precision Plus Protein All Blue Standards. Gels were run at RT in a Criterion Cell vertical 
electrophoresis buffer tank (Bio-Rad, Hercules, CA, USA) containing a $1 \times$ dilution of XT MOPS running buffer at $80 \mathrm{~V}$ for $15 \mathrm{~min}$. Voltage was then increased to $120 \mathrm{~V}$ for the duration of the electrophoretic run (approximately $100 \mathrm{~min}$ ).

2.8.2. 1D-western blotting-Proteins in the gel were transferred to a nitrocellulose membrane $(0.2 \mathrm{~nm})$ using a Trans-Blot Turbo ${ }^{\mathrm{TM}}$ Blotting System (Bio-Rad, Hercules, CA, USA). After the transfer, membranes were placed in a blocking solution of $3 \%$ bovine serum albumin (BSA) in Wash Blot [150 mM NaCl, $3 \mathrm{mM} \mathrm{NaH}_{2} \mathrm{PO}_{4}, 17 \mathrm{mM} \mathrm{NaHPO}_{4}$ and $0.04 \%$ (v/v) Tween 20] at RT for $1.5 \mathrm{~h}$. Alpha-internexin and anti-chloride intracellular channel proteins were detected with polyclonal primary antibodies raised in rabbits (1:8000 dilution in blocking solution.) Blots were incubated at RT with gentle rocking for $2 \mathrm{~h}$. Next, the membranes were rinsed three times in Wash Blot ( $5 \mathrm{~min}, 5 \mathrm{~min}, 10 \mathrm{~min}$ ), followed by a $1 \mathrm{~h}$ incubation with a rabbit horseradish peroxidase (1:3000) secondary antibody at RT with gentle rocking. Blots were rinsed three times (5,10 and $10 \mathrm{~min}$ ) in Wash Blot and developed chemiluminescently using Clarity ${ }^{\mathrm{TM}}$ Western ECL Substrate. After developing for $5 \mathrm{~min}$ at RT in the dark, blots were scanned using a Bio-Rad ChemiDoc ${ }^{\mathrm{TM}} \mathrm{XRS}+$ imaging system and quantified using Image Lab software (Bio-Rad, Hercules, CA, USA). The membranes were then rinsed with Wash Blot for 5 min, two times, and then stripped with Re-Blot Plus Strong solution for exactly $10 \mathrm{~min}$ at RT, followed by three 5 min rinses with Wash Blot. The membranes were then blocked once again in $3 \%$ BSA for $1.5 \mathrm{~h}$. Next, anti-tubulin antibodies raised in mice $(1: 20,000)$ were added to the Wash Blot solution for $2 \mathrm{~h}$ of gentle rocking at RT. Membranes were then washed, incubated with a secondary HRP-conjugated antibody, washed, developed chemiluminescently and scanned as described above.

\subsection{Statistical analysis}

An ANOVA was performed followed by a Bonferroni correction for multiple comparisons in order to determine the effects of HFS and HFS+RSV diets on the expression of proteins within the tissue of the parietal lobule. An $a<0.05$ was selected as a measure of significance for the ANOVA while a $P<.05$ was selected as a measure of significance for the multiple comparisons test. Fold-change values of differentially expressed proteins were determined by dividing the average spot intensity of the gels from the HFS or HFS+RSV diet groups by the average spot intensity of the gels of the Cont diet group. For the fold-change comparisons between the HFS and the HFS+R, the average spot intensities of the gels from the HFS+RSV were divided by those of the gels from the HFS diet. Proteins that were identified by the SEQUEST search algorithm with $P<.01$ were considered to be statistically significant. To further validate MS/MS identification of significant differentially expressed proteins, the position of protein spots on the 2D-gel images were manually examined to confirm that they were located near the expected molecular weight and isoelectric point values from the SwissProt database information.

\section{Results}

\subsection{Proteomics}

Proteomic identifications of proteins from rhesus monkey parietal lobules following 2 years of a diet intervention were conducted using a 2D-PAGE approach with Sypro Ruby staining. 
Protein spot intensities were compared between these three groups to determine differentially expressed proteins. Fig. 1 shows representative examples of 2-D gel images of the isolated proteins for the Cont and HFS comparison with the five differentially expressed proteins identified and listed in Table 1. Gel images for the Cont and HFS+RSV comparison are shown in Fig. 2. Six proteins were identified and listed in Table 2. Fig. 3 illustrates the four differentially expressed proteins between HFS and HFS+RSV diet groups which are listed in Table 3. PDQuest analysis of 2-D images for all three groups identified protein spots suitable for extraction and whose expression was significantly altered in the parietal lobules, and five of the proteins were significant in multiple comparisons. Protein spot extraction was followed by in-gel trypsin digestion, peptide extraction, removal of metal ions with buffers, and MS/MS analysis coupled to interrogation of protein databases. All proteins were identified by more than one peptide sequence.

Fold-change values were calculated by dividing the average spot intensity of the gel protein spots of the HFS or HSF+RSV diet group by the average spot intensity of the Cont diet gel spots, or by dividing the average spot intensity of the gel protein spots of the HFS+RSV by the average spot intensity of the gel protein spots of the HFS diet. To expound, a fold increase of 1.75 in the HFS+RSV group represents a 75\% increase in protein level of the HFS+RSV group compared to the group used as a Cont in the comparison. Moreover, a fold value $<1$, denotes a decrease in protein level; for example, a fold-change of 0.25 represents a decreased protein level of $75 \%$.

\subsection{Western blot validation experiments}

Western blot experiments were conducted on a selected protein to validate the changes in protein levels as determined by the PDQuest analysis of the 2-D gels. Fig. 4 is a Western blot image of the three groups after probing with chloride intracellular channel protein and tubulin antibodies. Analysis of this blot showed a $65.6 \%$ decrease in levels of chloride intracellular channel protein in the HFS group compared to Cont $(P=.008)$, as well as a $72.3 \%$ decrease in HFS+RSV compared to Cont $(P=.0051)$. PDQuest data from the protein spot identified as chloride intracellular channel protein by MS/MS analysis showed a $98.7 \%$ decrease in levels from the Cont diet to the HFS diet ( $P=.0234)$, and a $62.77 \%$ decrease in levels from the Cont diet to the HFS+RSV diet ( $P=.0294)$. Fig. 5 is the Western blot image of the samples after probing with a primary alpha-internexin antibody, whereas tubulin was the loading control. The HFS group demonstrated only a trend $(P=.059)$ toward a decrease compared to Cont despite a $32.8 \%$ reduced levels of alpha-internexin. HFS+RSV had a $41.7 \%$ increase in levels of alpha-internexin compared to the HFS group $(P=.0159)$ but was not different from Cont. The variations in fold changes between the two detection methods may be attributed to the sensitivity of the Sypro Ruby staining method of the 2-D gels contrasted to the range limitations involved with the chemiluminescent development of the 1-D Western blot. These validation experiments support the findings in the proteomics identification of the main proteins in the study. 


\section{Discussion}

Discovery-based expression proteomics was used to compare the effects of three experimentally controlled dietary conditions in adult male rhesus monkeys: a standard healthy control diet, a Westernized diet high in fat and sugar, and the HFS diet supplemented with RSV. Eleven proteins were identified in the HFS groups with a significant differential expression when compared to Cont diet monkeys. The functions of these proteins vary greatly but all can be considered contributing to the proper functioning of biological systems such as metabolism, structural integrity, neurotransmission, and cellular signaling. RSV's greatest effects reportedly occur within a metabolically impaired state such as obesity and diabetes, while healthy individuals benefit less [19-23]. A recent study published by collaborators using the monkeys from which our samples were derived measured the levels of RSV in the CSF of HFS+R, but were unable to detect RSV in the Cont and HFS groups demonstrating the efficacy of the RSV supplementation [24]. Moreover, they were able to measure SIRT1 and SIRT2 levels and activity (via acetylated tubulin). While it was found that SIRT1 levels were unchanged across the three groups, the HFS+R group had a significant reduction in SIRT2 levels that accompanied an increase in expression of atubulin and a reduction in the ratio of acetylated tubulin/total tubulin, of which the authors suggest may be due to compensatory mechanisms of acetylation [24].

Here, we identified a number of parietal lobe proteins of differential levels in monkeys consuming an HFS diet for 2 years. In several, but not all cases RSV supplementation was associated with a change in the expression profile suggestive of improved function. Those proteins exhibiting level changes associated with treatment are classified here by cellular sub-systems and discussed in that context. A graphical illustration of the protein and a primary canonical function is provided in Fig. 6.

\subsection{Energy}

The production and maintenance of cellular stores of energy is a complex and necessary function of all systems within an organism, however, the brain is unique in its energy consumption needs. The brain is a small fraction of the total mass of an organism, yet it consumes upwards of $30 \%$ of all inspired oxygen and $20 \%$ of ingested glucose for its energy needs. This energy is used to maintain neuronal cell resting potentials, neurotransmitter production and release, as well as the propagation of action potentials, among other functions. Moreover, the brain is highly dependent upon glucose for its functioning, and any severe decrease in glucose metabolism may prove to be detrimental to the health of the organism. Therefore, an analysis of proteomic changes to the levels of metabolic enzymes as a function of diet could prove useful in understanding the effects of a Western diet and/or resveratrol supplementation on the brain.

A number of glycolytic enzymes were identified as having altered protein levels. Pyruvate kinase and phosphoglycerate kinase 1 were significantly decreased (0.11-fold and 0.71-fold, respectively) in the HFS group compared to Cont. As glucose is the primary source of energy for the brain, we posit that the observed decrease in these two glycolytic enzymes following 2 years on HFS diet represent energy impairment imparted by the unhealthy diet. Resveratrol supplementation to an HFS diet appeared to preferentially act on ENO1 levels as 
alpha-enolase (ENO1) was 3.15-fold higher in the HFS+RSV compared to HFS group. ENO1, is most commonly known for its role in glycolysis in which it catalyzes the production of phosphoenolpyruvate from 2-phosphoglycerate. A loss of glycolytic enzymes could potentially have a negative effect on the efficiency of glucose utilization and thus, normal brain function. However, ENO1 is a pleiotropic enzyme with many functions beyond glucose metabolism. ENO1 has been shown to exhibit functions of a heat shock protein, a hypoxic-stress protein, a neurotrophic factor, as well as a transcription modulator [25]. Enolase has been found to be compromised in several neurodegenerative diseases such as AD, Huntington's disease, and amyotrophic lateral sclerosis [26-28].

BACH protein was 58.2-fold lower in the HFS monkey parietal lobe compared to Cont. BACH cleaves acyl-CoA into coenzyme-A (CoASH) and the resultant fatty acid. Fatty acids, acyl-CoA, and CoA-SH all serve diverse biological functions important in processes such as $\beta$-oxidation and metabolism in general, lipid synthesis, gene regulation, cellular signaling, and enzymatic regulation. Additionally, within the brain, they serve as an energy source, and in the process of lipid synthesis and homeostasis, cellular signaling, enzyme regulation, vesicle trafficking, and gene expression, bio-molecular trafficking, and ion flux [29-32]. $\mathrm{BACH}$ has been found to be crucial in preventing neurotoxicity via dysregulation of fatty acid metabolism while also regulating cell and membrane stability, potentially impacting the aging rate $[30,33]$. BACH is more active in the brain than in any other organ system and our data suggest that long-term consumption of an HFS diet by a nonhuman primate may impair its expression levels. This finding may have direct implications on healthy brain function as previous research has indicated that functioning $\mathrm{BACH}$ provides protection from neurotoxicity [32].

\subsection{Structure}

Microtubules are structural protein complexes that provide structural integrity to the cell, as well as roles in cellular processes such as cell division, ciliary/flagellar movement, and intracellular transport. Microtubules are composed of alpha- and beta-tubulin that selfassemble into large polymers. However, due to rapidly changing complex needs of the cell, microtubules must be dynamic in their construction and deconstruction. Stathmin is a key protein in the regulation of microtubule assembly and disassembly and impedes formation of microtubules through the sequestration of soluble tubulin into T2S complexes [34]. Therefore, the levels of stathmin may directly affect microtubule turnover and dynamics. Moreover, an overexpression of stathmin is found to be present in various forms of cancers and in $\mathrm{AD}$ progression, while also being positively correlated to telomere shortening $[35,36]$. In the current study, monkeys fed HFS+RSV have a 0.69-fold decrease of stathmin compared to HFS fed monkeys. This decrease in stathmin may allow for increased microtubule formation and stability, consistent with more efficient intracellular transport of vesicles and mitochondria.

Collapsin response mediator protein-2 (CRMP-2; also called dihydropyrimidinase-related protein 2 (DRP-2)) is important in the proper functioning of neurons, and its aberrant expression and/or inactivity has been implicated in neurodegenerative diseases such as AD $[37,38]$. The primary roles of CRMP-2 are control of the dynamic stability of microtubules, 
neural differentiation and specification for axons and dendrites, the proper outgrowth/ retraction of neurites, neurotransmitter release, indirect control of axonal transport, and calcium homeostasis [37,39-42]. CRMP-2 is the only CRMP to be maintained at high levels in adult neurons and is mostly expressed in areas requiring high degrees of plasticity such as the hippocampus, cerebellum, and olfactory bulb [43]. Within the neuron, CRMP-2 is found within the growth cone and synapses, indicative of its function [44]. Here, we showed that levels of CRMP-2 are significantly reduced in HFS and HFS+RSV compared to Cont at 0.079-fold and 0.098-fold, respectively. These data indicate that CRMP-2 may be decreased in response to a HFS, unhealthy diet and RSV was not protective in monkeys. The implementations of this reduced level is that neuritic extensions would be shorter, thereby making fewer synaptic connections. HFS could therefore lead to detrimental cognitive changes.

Oligodendrocytes are one of the major cell types of the CNS as a component of the myelin sheath, wrapping around the adjacent neuronal axons to allow saltatory impulse propagation. Oligodendrocytes are associated with 2,3-cyclic nucleotide 3-phosphodiesterase (CNP), which plays an important, albeit not well understood, role in myelin formation. CNP is located in non-compacted myelin regions while absent in compacted sheath [45,46]. LappeSeifke et al. silenced the Cnplgene in mice, which resulted in fully myelinated offspring, but with severe axonal swelling and death by 12 months [47]. In Cnp-1 null mice, the absence of CNP led to disorganized oligodendroglial paranodes and altered communication between neuronal axons and oligodendrocytes and consequential neurodegeneration [48]. In our HFS $+\mathrm{RSV}$ fed nonhuman primates, CNP was down regulated 0.492-fold compared to the HFSfed group indicating that RSV supplementation appears to have a detrimental impact on CNP performance.

Vacuolar H+-ATPases (V-Type ATPase) have a structure and mechanistic action similar to that of F-Type ATPases, which are found in the inner mitochondrial membrane and used for oxidative phosphorylation, yet the ultimate function they perform differs. While F-Type ATPases use proton gradients to drive ATP production, V-Type ATPases use ATP to drive proton gradients [49]. The establishment of an electrochemical proton gradient across a lipid bilayer is used in a variety of processes from the acidification of lysosomal luminal space, to the packaging of neurotransmitters into synaptic vesicles and endocytic transportation [50]. For instance, the environment of an endocytic vesicular lumen made acidic in comparison to the surrounding cytosol by V-Type ATPases allows for the dissociation of ligands and receptors for recycling of the components [51]. In regards to protein degradation and turnover, V-Type ATPases play an important role in the autophagic pathway in direct and possibly indirect manners. First, V-Type ATPases directly acidify the lysosomal luminal space to a $\mathrm{pH}$ of around 4.5 in order to provide an optimal environment for lysosomal protease functioning [50,52]. A less well characterized function of V-Type ATPases in regards to induction of autophagy is their proposed ability to activate lysosomal bound mTORC1, a required step for mTORC1 activation. It is hypothesized that due to V-Type ATPases interaction with both mTORC1 and Regulator, that V-Type ATPases may sense levels of available amino acids and convey that information to mTORC1 [53-55]. In this study, we found a significant increase in isoform 3 of V-Type proton ATPase subunit E-1 protein level (4.67-fold) in the HFS+RSV group compared to Cont. We hypothesize that an 
increase in V-Type ATPase levels with RSV supplementation represents the cellular attempt at an autophagy response as needed while preserving the necessary brain functions such as neurotransmitter processing and lysosomal efficacy.

\subsection{Signaling}

One method of signal transduction is through the activation of transmembrane G-protein coupled receptors (GPCRs). GPCRs participate in many signaling and physiological functions such as neurotransmission, peptide hormone signaling, vision, taste, and smell [56]. GPCRs have a small G-protein docked to the intracellular side of the receptor, which upon receptor activation is itself activated by the replacement of GDP with GTP in its regulatory site causing the $G$-protein to split into $G_{\alpha}$ and $G_{\beta \gamma}$ subunits. Upon activation of the $\mathrm{G}_{\mathrm{a}}$-subunit by GTP, the $\mathrm{G}_{\mathrm{a}}$-subunit is free to activate downstream effectors such as adenylate cyclase (AC), a signal amplifying enzyme that creates the secondary messenger cyclic-AMP (cAMP) from ATP. Following this process, the $\mathrm{G}_{\mathrm{a}}$-subunit's GTPase activity slowly turns the GTP back to GDP, deactivating itself to start the cycle anew. Guanine nucleotide-binding protein $\left(\mathrm{G}_{\mathrm{i}} / \mathrm{G}_{\mathrm{s}} / \mathrm{G}_{\mathrm{t}}\right)-1$ (GNB1), the $\beta$ subunit, is responsible for the GTPase activity, which allows for the activation of the G-protein, guanine nucleotide exchange, and also for downstream signaling of the G $\beta \gamma$ complex [57]. In the present study, the HFS+RSV diet led to an increase in GNB1 by 3.61-fold over that of the brain of monkeys fed the HFS diet alone, whereas GNB1 was found to have a significant decrease in levels (0.07-fold) in the HFS compared to Cont. The results suggest that while the HFS diet alone may have a detrimental role in levels of GNB1, RSV may attenuate that loss, suggestive of a protective effect. GNB1 is necessary for the direct activation of downstream effects such as phosphoinositide-3-kinase, phospholipase-C isoforms, and ion channels, while indirectly participating in all $\mathrm{Ga}$ activities due to their regulatory nature over the $\mathrm{Ga}$ subunit [58]. Here, our proteomics studies are consistent with the notion that addition of RSV to a HFS diet promotes cellular signaling in brain that is diminished in brain of HFSfed monkey group.

Glutamine synthetase is a key protein of astrocytes in the brain as it is involved in the glutamate-shuttle and subsequent conversion of the neurotransmitter glutamate to inactive glutamine prior to being translocated back to the neuron. The glutamate shuttle is important for the health of the neuron as glutamate is an excitatory neurotransmitter which if left in the synapse and not converted to glutamine may cause excitotoxicity and subsequently neuron death through calcium dysregulation [59]. However, the glutamine shuttle is not solely responsible for glutamate availability at the synapse [60]. We report that glutamine synthetase has significantly reduced levels (0.74-fold) in the HFS+RSV when compared to Cont, and decreased but not significantly decreased levels in HFS compared to Cont suggesting that the HFS diet depressed levels of glutamine synthetase that are not recovered, and perhaps even exacerbated, with RSV supplementation. It has been suggested in a $3 \times-$ TG-AD mouse model that depression of glutamine synthetase levels may lead to errant glutamate homeostasis and regulation as well as memory and cognitive impairment that may be attributed to failures in synaptic connectivity, all of which are apparent in human AD [61]. 
Chloride intracellular channel protein 4 (CLC-4) is a multifunctional protein predominantly known for its role as a chloride channel, as its name implies. However, CLCs have recently been shown to participate in other physiological roles such as a mediator of apoptosis in which this protein is translocated to the nucleus $[62,63]$. The suppression of CLC-4 with siRNA is reported to be involved in enhanced hydrogen peroxide mediated apoptotic activation [64], whereas others showed siRNA interference of CLC-4 enhanced TNFamediated apoptosis in a p53-independent manner [65]. However, the role of CLC-4 in apoptosis is complex, as demonstrated by its ability to be highly apoptotic in and of itself when Apaf1 is deleted, inhibiting the mitochondrial apoptotic pathway [66]. Here, we show a significant decrease in CLC-4 in both the HFS vs Cont and HFS+RSV vs Cont groups with 0.01 -fold and 0.37 -fold protein level of control, respectively. We posit that this decrease in CLC-4 levels in both unhealthy diet groups is indicative of potential apoptotic regulation, and as oxidative stress is a hallmark of both diabetes and $\mathrm{AD}$, it is possible that hydrogen peroxide mediated apoptosis is in part responsible for cognitive deficiencies, though followup research is needed to clarify this speculation.

SH3 domain-binding glutamic acid-rich-like protein (SH3BGRL) is homologous to glutaredoxin 1 in E. coli, an oxioreductase, thought to belong to the thioredoxin-like protein family [67]. SH3BGRL2, a homolog of the SH3BGRL family, was later identified and shown to have a high similarity to other SH3BGRL homolog N-terminal region [68]. While SH3BGRL proteins may belong to the thioredoxin-like super family of proteins, all homologs are devoid of the CXXC motif indicating that they most likely do not have any thioredoxin-like enzymatic activity [68]. However, due to its shared homology, specifically to that of glutaredoxin, it is possible that SH3BGRL proteins participate in the regulation of redox sensitive proteins, possibly through the action of its PICOT homology domain, allowing it to engage in protein-protein interactions hinting at its role as a protein regulator [68]. Research supports the notion of SH3BGRL protein SH3BGRL3 as acting as an indirect inhibitor of TNF- $a$ through the activation of NF- $\kappa$ B by way of its PICOT homology $[69,70]$. Here we observed a decreased level of SH3BGRL2 (0.69-fold) in HFS+RSV diet fed monkeys vs Cont monkeys. As both SH3GBRL2/3 share similar PICOT homology, it is possible that RSV supplementation in an HFS diet modulates the inflammatory response through SH3BGRL2/3 decrease of active TNF- $a$ and subsequently modulating the inflammatory response, though this speculation needs further study to confirm.

\section{Conclusion}

Using proteomics, we have identified a number of proteins with differential expression in the parietal lobule of adult male rhesus monkeys fed Cont, HFS or HFS+RSV diets over a duration of two years. Our findings suggest potential improvements in energy metabolism, efficiency of canonical cell signaling pathways, and neurotransmission with RSV supplementation to an HFS diet. In contrast, some brain protein levels such as CNP and glutamine synthetase may not be attenuated by RSV supplementation of an unhealthy diet. While it has been shown in other studies that resveratrol addition to a normal diet may not provide significant benefits to healthy individuals, it has been observed that resveratrol does lead to marked improvement in individuals already exhibiting signs of metabolic syndrome $[19,21,22]$. Our studies contribute to the understanding of the changes occurring in the 
proteome of the dietary-impaired parietal lobule of non-human primates given resveratrol supplementation.

\section{Acknowledgments}

This study was funded in part by the Intramural Research program of the National Institute on Aging, NIH. We thank the National Institute on Aging for providing the brain samples used in this study.

\section{References}

1. Myles IA. Fast food fever: reviewing the impacts of the western diet on immunity. Nutr J. 2014; 13:61. [PubMed: 24939238]

2. Bastianetto S, Menard C, Quirion R. Neuroprotective action of resveratrol. Biochim Biophys Acta. 2014; 1852:1195-201. [PubMed: 25281824]

3. Poulsen MM, Fjeldborg K, Ornstrup MJ, Kjaer TN, Nohr MK, Pedersen SB. Resveratrol and inflammation: challenges in translating pre-clinical findings to improved patient outcomes. Biochim Biophys Acta. 2014; 1852:1124-36.

4. Szkudelski T, Szkudelska K. Resveratrol and diabetes: from animal to human studies. Biochim Biophys Acta. 2014; 1852:1145-54. [PubMed: 25445538]

5. Carrizzo A, Forte M, Damato A, Trimarco V, Salzano F, Bartolo M, et al. Antioxidant effects of resveratrol in cardiovascular, cerebral and metabolic diseases. Food Chem Toxicol. 2013; 61:21526. [PubMed: 23872128]

6. Howitz KT, Bitterman KJ, Cohen HY, Lamming DW, Lavu S, Wood JG, et al. Small molecule activators of sirtuins extend Saccharomyces cerevisiae lifespan. Nature. 2003; 425(6954):191-6. [PubMed: 12939617]

7. Blander G, Guarente L. The Sir2 family of protein deacetylases. Annu Rev Biochem. 2004; 73:41735. [PubMed: 15189148]

8. Park SJ, Ahmad F, Philp A, Baar K, Williams T, Luo H, et al. Resveratrol ameliorates aging-related metabolic phenotypes by inhibiting cAMP phosphodiesterases. Cell. 2012; 148(3):421-33. [PubMed: 22304913]

9. Dai H, Kustigian L, Carney D, Case A, Considine T, Hubbard BP, et al. SIRT1 activation by small molecules: kinetic and biophysical evidence for direct interaction of enzyme and activator. J Biol Chem. 2010; 285(43):32695-703. [PubMed: 20702418]

10. Brickman AM, Zahodne LB, Guzman VA, Narkhede A, Meier IB, Griffith EY, et al. Reconsidering harbingers of dementia: progression of parietal lobe white matter hyperintensities predicts Alzheimer's disease incidence. Neurobiol Aging. 2015; 36(1):27-32. [PubMed: 25155654]

11. Teixeira S, Machado S, Velasques B, Sanfim A, Minc D, Peressutti C, et al. Integrative parietal cortex processes: neurological and psychiatric aspects. J Neurol Sci. 2014; 338(1-2):12-22. [PubMed: 24398346]

12. Cosottini M, Pesaresi I, Piazza S, Diciotti S, Cecchi P, Fabbri S, et al. Structural and functional evaluation of cortical motor areas in amyotrophic lateral sclerosis. Exp Neurol. 2012; 234(1):16980. [PubMed: 22226599]

13. Di Domenico F, Owen JB, Sultana R, Sowell RA, Perluigi M, Cini C, et al. The wheat germ agglutinin-fractionated proteome of subjects with Alzheimer's disease and mild cognitive impairment hippocampus and inferior parietal lobule: implications for disease pathogenesis and progression. J Neurosci Res. 2010; 88(16):3566-77. [PubMed: 20936705]

14. Aluise CD, Robinson RA, Cai J, Pierce WM, Markesbery WR, Butterfield DA. Redox proteomics analysis of brains from subjects with amnestic mild cognitive impairment compared to brains from subjects with preclinical Alzheimer's disease: insights into memory loss in MCI. J Alzheimers Dis. 2011; 23(2):257-69. [PubMed: 20930294]

15. Baur JA, Pearson KJ, Price NL, Jamieson HA, Lerin C, Kalra A, et al. Resveratrol improves health and survival of mice on a high-calorie diet. Nature. 2006; 444(7117):337-42. [PubMed: 17086191] 
16. Fiori JL, Shin YK, Kim W, Krzysik-Walker SM, Gonzalez-Mariscal I, Carlson OD, et al. Resveratrol prevents beta-cell dedifferentiation in nonhuman primates given a high-fat/high-sugar diet. Diabetes. 2013; 62(10):3500-13. [PubMed: 23884882]

17. Jimenez-Gomez Y, Mattison JA, Pearson KJ, Martin-Montalvo A, Palacios HH, Sossong AM, et al. Resveratrol improves adipose insulin signaling and reduces the inflammatory response in adipose tissue of rhesus monkeys on high-fat, high-sugar diet. Cell Metab. 2013; 18(4):533-45. [PubMed: 24093677]

18. Mattison JA, Wang M, Bernier M, Zhang J, Park SS, Maudsley S, et al. Resveratrol prevents high fat/sucrose diet-induced central arterial wall inflammation and stiffening in nonhuman primates. Cell Metab. 2014; 20(1):183-90. [PubMed: 24882067]

19. Timmers S, Konings E, Bilet L, Houtkooper RH, van de Weijer T, Goossens GH, et al. Calorie restriction-like effects of 30days of resveratrol supplementation on energy metabolism and metabolic profile in obese humans. Cell Metab. 2011; 14(5):612-22. [PubMed: 22055504]

20. Ghanim H, Sia CL, Abuaysheh S, Korzeniewski K, Patnaik P, Marumganti A, et al. An antiinflammatory and reactive oxygen species suppressive effects of an extract of Polygonum cuspidatum containing resveratrol. J Clin Endocrinol Metab. 2010; 95(9):E1-8. [PubMed: 20534755]

21. Crandall JP, Oram V, Trandafirescu G, Reid M, Kishore P, Hawkins M, et al. Pilot study of resveratrol in older adults with impaired glucose tolerance. J Gerontol A Biol Sci Med Sci. 2012; 67(12):1307-12. [PubMed: 22219517]

22. Yoshino J, Conte C, Fontana L, Mittendorfer B, Imai S, Schechtman KB, et al. Resveratrol supplementation does not improve metabolic function in nonobese women with normal glucose tolerance. Cell Metab. 2012; 16(5):658-64. [PubMed: 23102619]

23. Marchal J, Blanc S, Epelbaum J, Aujard F, Pifferi F. Effects of chronic calorie restriction or dietary resveratrol supplementation on insulin sensitivity markers in a primate, Microcebus murinus. PLoS One. 2012; 7(3):e34289. [PubMed: 22479589]

24. Bernier M, Wahl D, Ali A, Allard J, Faulkner S, Wnorowski A, et al. Resveratrol supplementation confers neuroprotection in cortical brain tissue of nonhuman primates fed a high-fat/sucrose diet. Aging (Albany NY). 2016; 8(5):899-916. [PubMed: 27070252]

25. Butterfield DA, Lange ML. Multifunctional roles of enolase in Alzheimer's disease brain: beyond altered glucose metabolism. J Neurochem. 2009; 111(4):915-33. [PubMed: 19780894]

26. Perluigi M, Fai Poon H, Hensley K, Pierce WM, Klein JB, Calabrese V, et al. Proteomic analysis of 4-hydroxy-2-nonenal-modified proteins in G93A-SOD1 transgenic mice-a model of familial amyotrophic lateral sclerosis. Free Radic Biol Med. 2005; 38(7):960-8. [PubMed: 15749392]

27. Perluigi M, Poon HF, Maragos W, Pierce WM, Klein JB, Calabrese V, et al. Proteomic analysis of protein expression and oxidative modification in $\mathrm{r} 6 / 2$ transgenic mice: a model of Huntington disease. Mol Cell Proteomics. 2005; 4(12):1849-61. [PubMed: 15968004]

28. Castegna A, Aksenov M, Thongboonkerd V, Klein JB, Pierce WM, Booze R, et al. Proteomic identification of oxidatively modified proteins in Alzheimer's disease brain. Part II: dihydropyrimidinase-related protein 2 , alpha-enolase and heat shock cognate 71 . J Neurochem. 2002; 82(6):1524-32. [PubMed: 12354300]

29. Hunt MC, Alexson SE. The role acyl-CoA thioesterases play in mediating intracellular lipid metabolism. Prog Lipid Res. 2002; 41(2):99-130. [PubMed: 11755680]

30. Hulbert AJ, Pamplona R, Buffenstein R, Buttemer WA. Life and death: metabolic rate, membrane composition, and life span of animals. Physiol Rev. 2007; 87(4):1175-213. [PubMed: 17928583]

31. Yamada J, Kuramochi Y, Takagi M, Watanabe T, Suga T. Human brain acyl-CoA hydrolase isoforms encoded by a single gene. Biochem Biophys Res Commun. 2002; 299(1):49-56. [PubMed: 12435388]

32. Yamada J. Long-chain acyl-CoA hydrolase in the brain. Amino Acids. 2005; 28(3):273-8. [PubMed: 15731883]

33. Ellis JM, Wong GW, Wolfgang MJ. Acyl coenzyme a thioesterase 7 regulates neuronal fatty acid metabolism to prevent neurotoxicity. Mol Cell Biol. 2013; 33(9):1869-82. [PubMed: 23459938] 
34. Curmi PA, Gavet O, Charbaut E, Ozon S, Lachkar-Colmerauer S, Manceau V, et al. Stathmin and its phosphoprotein family: general properties, biochemical and functional interaction with tubulin. Cell Struct Funct. 1999; 24(5):345-57. [PubMed: 15216892]

35. Ahn EY, Yoo JE, Rhee H, Kim MS, Choi J, Ko JE, et al. Increased expression of stathmin and elongation factor 1alpha in precancerous nodules with telomere dysfunction in hepatitis B viral cirrhotic patients. J Transl Med. 2014; 12:154. [PubMed: 24885363]

36. Belletti B, Baldassarre G. Stathmin: a protein with many tasks. New biomarker and potential target in cancer. Expert Opin Ther Targets. 2011; 15(11):1249-66. [PubMed: 21978024]

37. Hensley K, Venkova K, Christov A, Gunning W, Park J. Collapsin response mediator protein-2: an emerging pathologic feature and therapeutic target for neurodisease indications. Mol Neurobiol. 2011; 43(3):180-91. [PubMed: 21271304]

38. Butterfield DA, Perluigi M, Sultana R. Oxidative stress in Alzheimer's disease brain: new insights from redox proteomics. Eur J Pharmacol. 2006; 545(1):39-50. [PubMed: 16860790]

39. Goshima Y, Nakamura F, Strittmatter P, Strittmatter SM. Collapsin-induced growth cone collapse mediated by an intracellular protein related to UNC-33. Nature. 1995; 376(6540):509-14. [PubMed: 7637782]

40. Inagaki N, Chihara K, Arimura N, Menager C, Kawano Y, Matsuo N, et al. CRMP-2 induces axons in cultured hippocampal neurons. Nat Neurosci. 2001; 4(8):781-2. [PubMed: 11477421]

41. Hensley K, Christov A, Kamat S, Zhang XC, Jackson KW, Snow S, et al. Proteomic identification of binding partners for the brain metabolite lanthionine ketimine (LK) and documentation of LK effects on microglia and motoneuron cell cultures. J Neurosci. 2010; 30(8):2979-88. [PubMed: 20181595]

42. Yoshimura T, Kawano Y, Arimura N, Kawabata S, Kikuchi A, Kaibuchi K. GSK-3beta regulates phosphorylation of CRMP-2 and neuronal polarity. Cell. 2005; 120(1):137-49. [PubMed: 15652488]

43. Charrier E, Reibel S, Rogemond V, Aguera M, Thomasset N, Honnorat J. Collapsin response mediator proteins (CRMPs): involvement in nervous system development and adult neurodegenerative disorders. Mol Neurobiol. 2003; 28(1):51-64. [PubMed: 14514985]

44. Chu CC, Wang JJ, Chen KT, Shieh JP, Wang LK, Shui HA, et al. Neurotrophic effects of tianeptine on hippocampal neurons: a proteomic approach. J Proteome Res. 2010; 9(2):936-44. [PubMed: 20000655]

45. Trapp BD, Bernier L, Andrews SB, Colman DR. Cellular and subcellular distribution of $2^{\prime}, 3^{\prime}$ cyclic nucleotide $3^{\prime}$-phosphodiesterase and its mRNA in the rat central nervous system. $\mathrm{J}$ Neurochem. 1988; 51(3):859-68. [PubMed: 2842456]

46. Braun PE, Sandillon F, Edwards A, Matthieu JM, Privat A. Immunocytochemical localization by electron microscopy of $2^{\prime} 3^{\prime}$-cyclic nucleotide $3^{\prime}$-phosphodiesterase in developing oligodendrocytes of normal and mutant brain. J Neurosci. 1988; 8(8):3057-66. [PubMed: 2842470]

47. Lappe-Siefke C, Goebbels S, Gravel M, Nicksch E, Lee J, Braun PE, et al. Disruption of Cnp1 uncouples oligodendroglial functions in axonal support and myelination. Nat Genet. 2003; 33(3): 366-74. [PubMed: 12590258]

48. Rasband MN, Tayler J, Kaga Y, Yang Y, Lappe-Siefke C, Nave KA, et al. CNP is required for maintenance of axon-glia interactions at nodes of Ranvier in the CNS. Glia. 2005; 50(1):86-90. [PubMed: 15657937]

49. Nishi T, Forgac M. The vacuolar (H+)-ATPases-nature's most versatile proton pumps. Nat Rev Mol Cell Biol. 2002; 3(2):94-103. [PubMed: 11836511]

50. Maxson ME, Grinstein S. The vacuolar-type H(+)-ATPase at a glance - more than a proton pump. J Cell Sci. 2014; 127(23):4987-93. [PubMed: 25453113]

51. Maxfield FR, McGraw TE. Endocytic recycling. Nat Rev Mol Cell Biol. 2004; 5(2):121-32. [PubMed: 15040445]

52. Huynh KK, Grinstein S. Regulation of vacuolar $\mathrm{pH}$ and its modulation by some microbial species. Microbiol Mol Biol Rev. 2007; 71(3):452-62. [PubMed: 17804666] 
53. Zoncu R, Bar-Peled L, Efeyan A, Wang S, Sancak Y, Sabatini DM. mTORC1 senses lysosomal amino acids through an inside-out mechanism that requires the vacuolar $\mathrm{H}(+)$-ATPase. Science. 2011; 334(6056):678-83. [PubMed: 22053050]

54. Xu Y, Parmar A, Roux E, Balbis A, Dumas V, Chevalier S, et al. Epidermal growth factor-induced vacuolar $(\mathrm{H}+)$-atpase assembly: a role in signaling via mTORC1 activation. J Biol Chem. 2012; 287(31):26409-22. [PubMed: 22689575]

55. Bar-Peled L, Schweitzer LD, Zoncu R, Sabatini DM. Ragulator is a GEF for the rag GTPases that signal amino acid levels to mTORC1. Cell. 2012; 150(6):1196-208. [PubMed: 22980980]

56. Rosenbaum DM, Rasmussen SG, Kobilka BK. The structure and function of G-protein-coupled receptors. Nature. 2009; 459(7245):356-63. [PubMed: 19458711]

57. Oldham WM, Hamm HE. Heterotrimeric G protein activation by G-protein-coupled receptors. Nat Rev Mol Cell Biol. 2008; 9(1):60-71. [PubMed: 18043707]

58. Cabrera-Vera TM, Vanhauwe J, Thomas TO, Medkova M, Preininger A, Mazzoni MR, et al. Insights into G protein structure, function, and regulation. Endocr Rev. 2003; 24(6):765-81. [PubMed: 14671004]

59. Takahashi K, Foster JB, Lin CL. Glutamate transporter EAAT2: regulation, function, and potential as a therapeutic target for neurological and psychiatric disease. Cell Mol Life Sci. 2015; 72:3489506. [PubMed: 26033496]

60. Danbolt NC. Glutamate uptake. Prog Neurobiol. 2001; 65(1):1-105. [PubMed: 11369436]

61. Kulijewicz-Nawrot M, Sykova E, Chvatal A, Verkhratsky A, Rodriguez JJ. Astrocytes and glutamate homoeostasis in Alzheimer's disease: a decrease in glutamine synthetase, but not in glutamate transporter-1, in the prefrontal cortex. ASN Neuro. 2013; 5(4):273-82. [PubMed: 24059854]

62. Qian Y, Du YH, Tang YB, Lv XF, Liu J, Zhou JG, et al. ClC-3 chloride channel prevents apoptosis induced by hydrogen peroxide in basilar artery smooth muscle cells through mitochondria dependent pathway. Apoptosis. 2011; 16(5):468-77. [PubMed: 21373935]

63. Ryu SY, Peixoto PM, Teijido O, Dejean LM, Kinnally KW. Role of mitochondrial ion channels in cell death. Biofactors. 2010; 36(4):255-63. [PubMed: 20623547]

64. Xu Y, Kang J, Yuan Z, Li H, Su J, Li Y, et al. Suppression of CLIC4/mtCLIC enhances hydrogen peroxide-induced apoptosis in C6 glioma cells. Oncol Rep. 2013; 29(4):1483-91. [PubMed: 23380911]

65. Suh KS, Mutoh M, Gerdes M, Crutchley JM, Mutoh T, Edwards LE, et al. Antisense suppression of the chloride intracellular channel family induces apoptosis, enhances tumor necrosis factor \{alpha\}-induced apoptosis, and inhibits tumor growth. Cancer Res. 2005; 65(2):562-71. [PubMed: 15695400]

66. Suh KS, Mutoh M, Nagashima K, Fernandez-Salas E, Edwards LE, Hayes DD, et al. The organellular chloride channel protein CLIC4/mtCLIC translocates to the nucleus in response to cellular stress and accelerates apoptosis. J Biol Chem. 2004; 279(6):4632-41. [PubMed: 14610078]

67. Egeo A, Mazzocco M, Arrigo P, Vidal-Taboada JM, Oliva R, Pirola B, et al. Identification and characterization of a new human gene encoding a small protein with high homology to the prolinerich region of the SH3BGR gene. Biochem Biophys Res Commun. 1998; 247(2):302-6. [PubMed: 9642120]

68. Mazzocco M, Maffei M, Egeo A, Vergano A, Arrigo P, Di Lisi R, et al. The identification of a novel human homologue of the SH3 binding glutamic acid-rich (SH3BGR) gene establishes a new family of highly conserved small proteins related to thioredoxin superfamily. Gene. 2002; 291(12):233-9. [PubMed: 12095696]

69. Witte S, Villalba M, Bi K, Liu Y, Isakov N, Altman A. Inhibition of the c-Jun N-terminal kinase/ AP-1 and NF-kappaB pathways by PICOT, a novel protein kinase C-interacting protein with a thioredoxin homology domain. J Biol Chem. 2000; 275(3):1902-9. [PubMed: 10636891]

70. Xu C, Zheng P, Shen S, Xu Y, Wei L, Gao H, et al. NMR structure and regulated expression in APL cell of human SH3BGRL3. FEBS Lett. 2005; 579(13):2788-94. [PubMed: 15907482] 


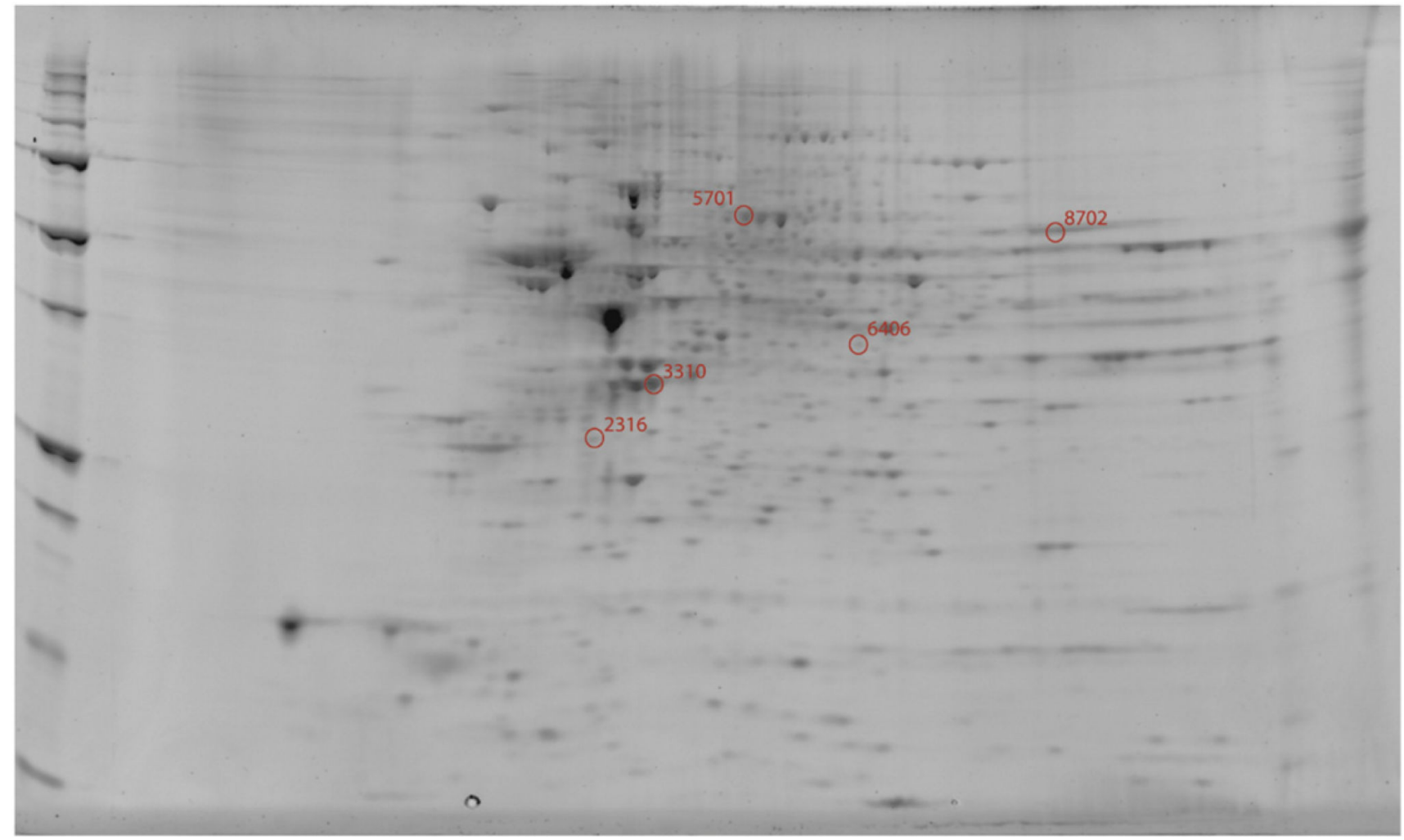

Fig. 1.

Representative 2-D gel image with identified protein spots for the Cont $v s$. HFS fed diet comparison. 


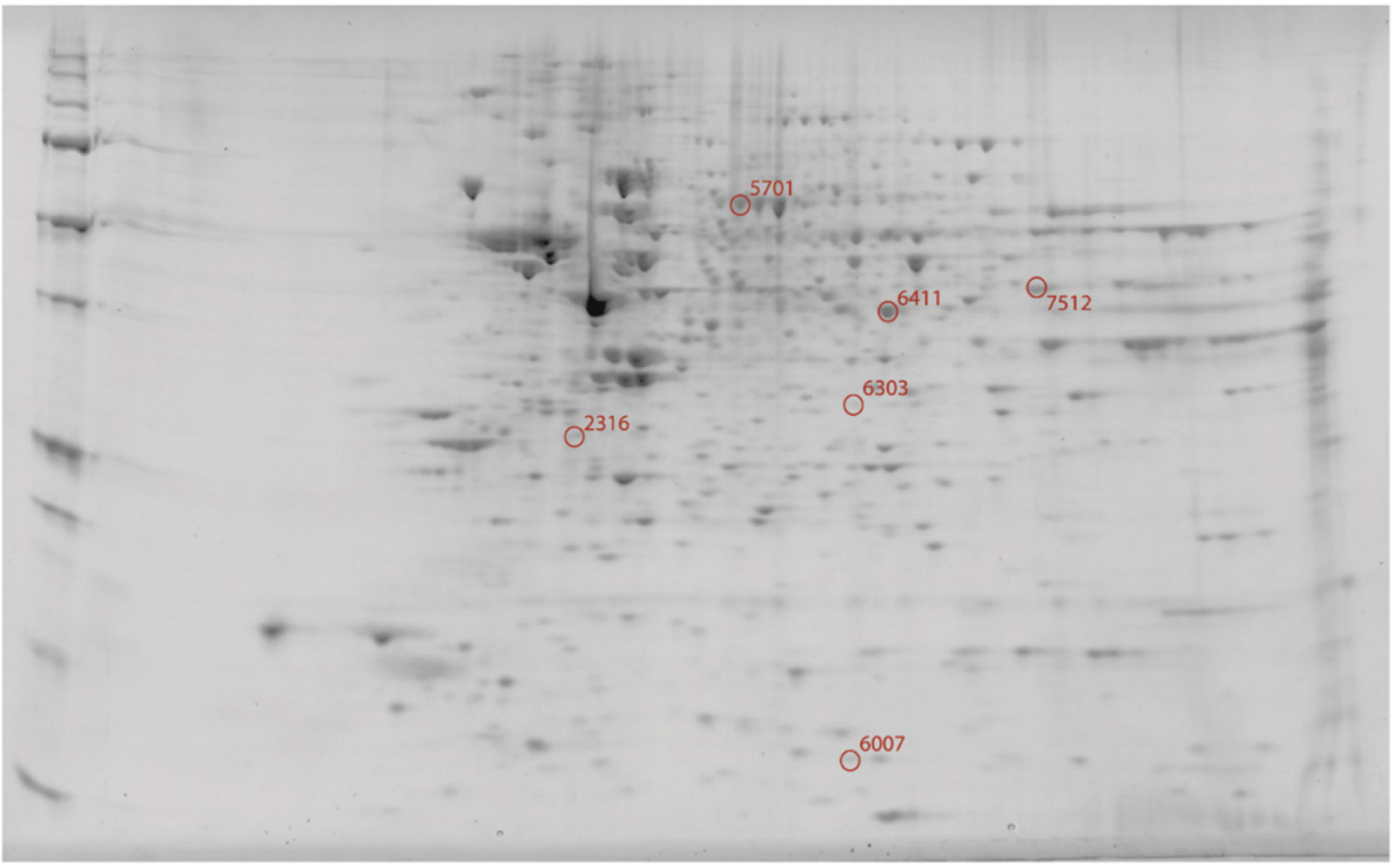

Fig. 2.

Representative 2-D gel image with identified protein spots for the Cont $v s$. HFS+RSV fed diet comparison. 


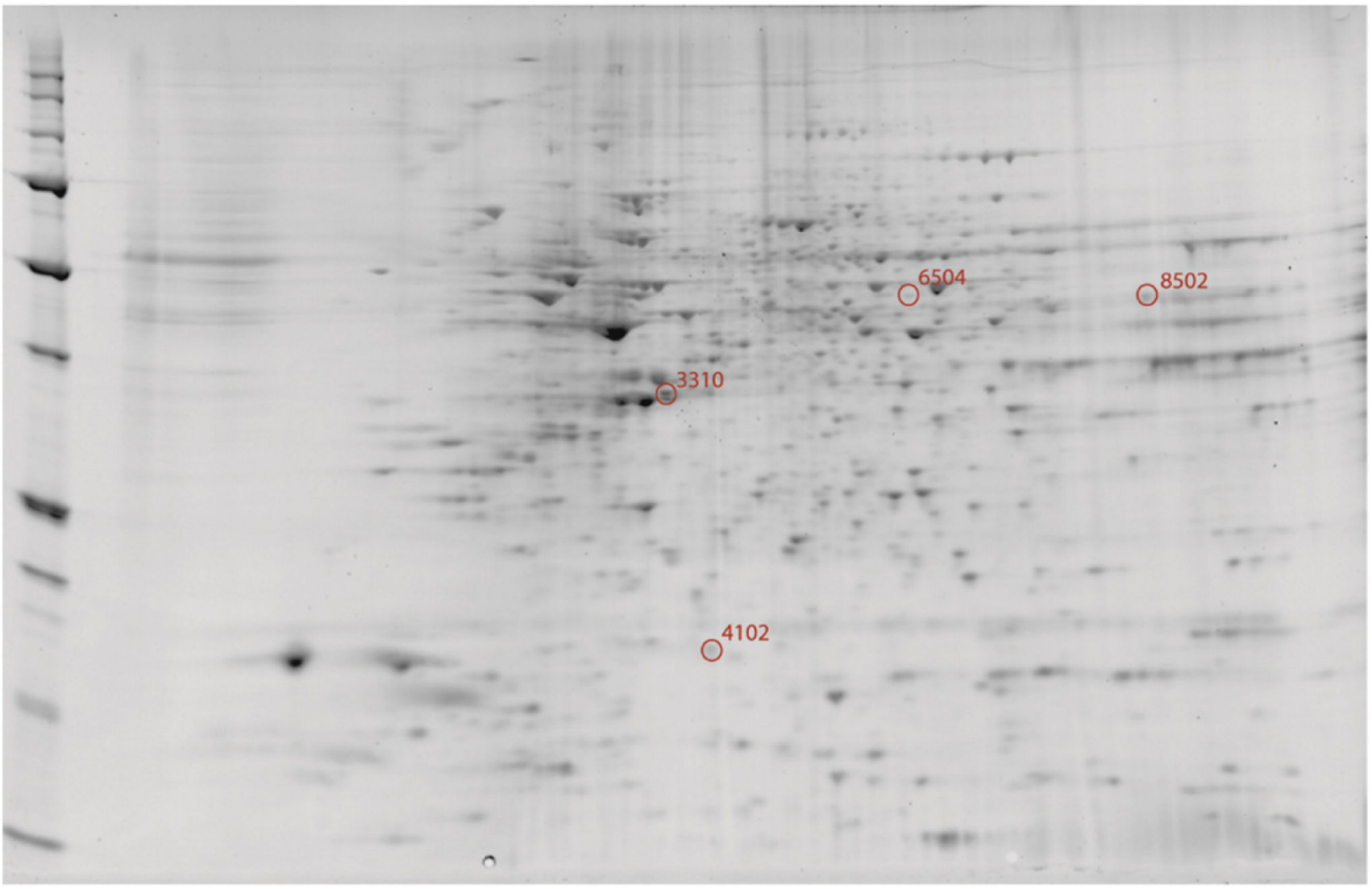

Fig. 3.

Representative 2-D gel image with identified protein spots for the HFS vs. HFS+RSV fed diet comparison. 

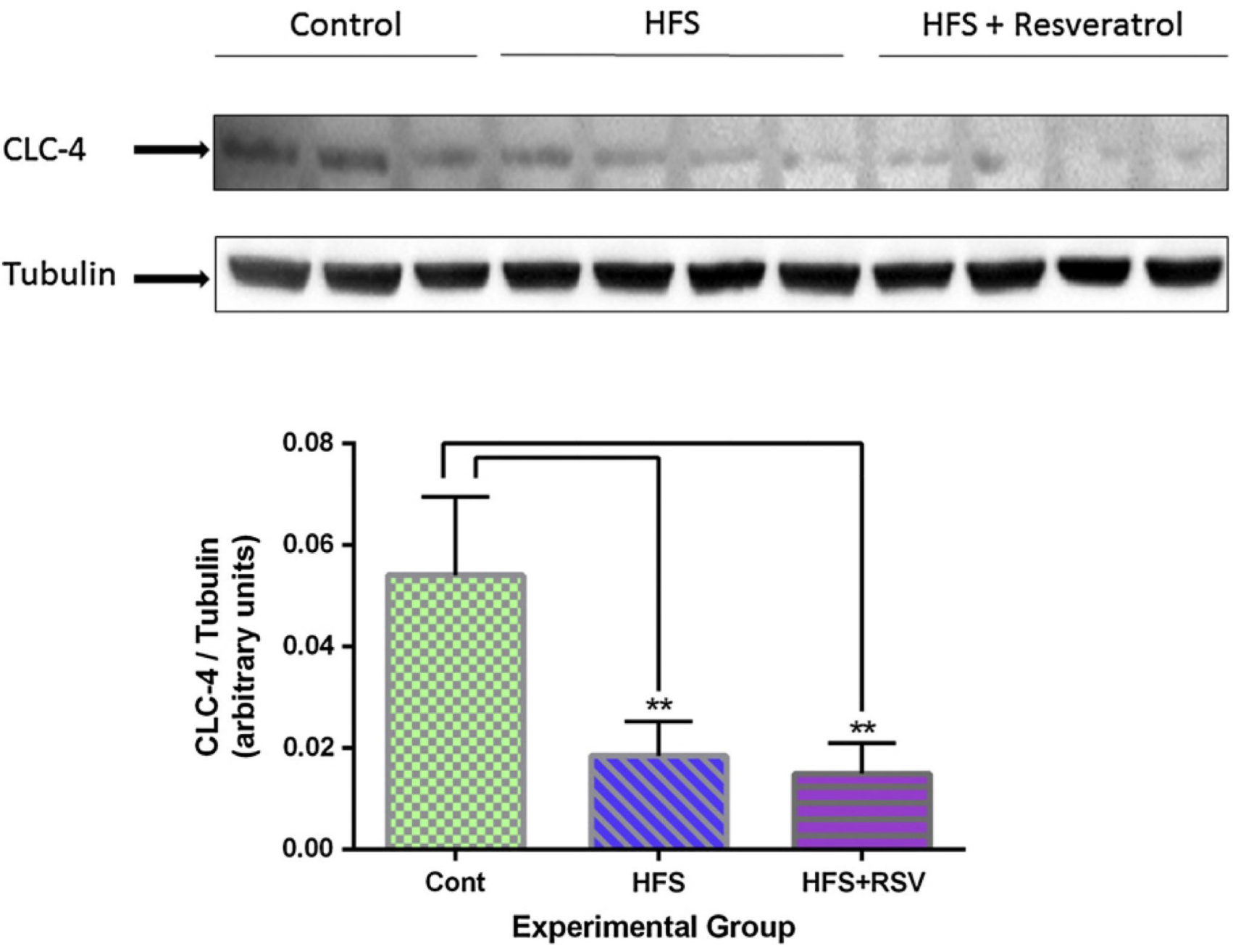

Fig. 4.

Western blot validation of CLC-4 levels across each group normalized against tubulin (**P $\leq$ $01)$. 

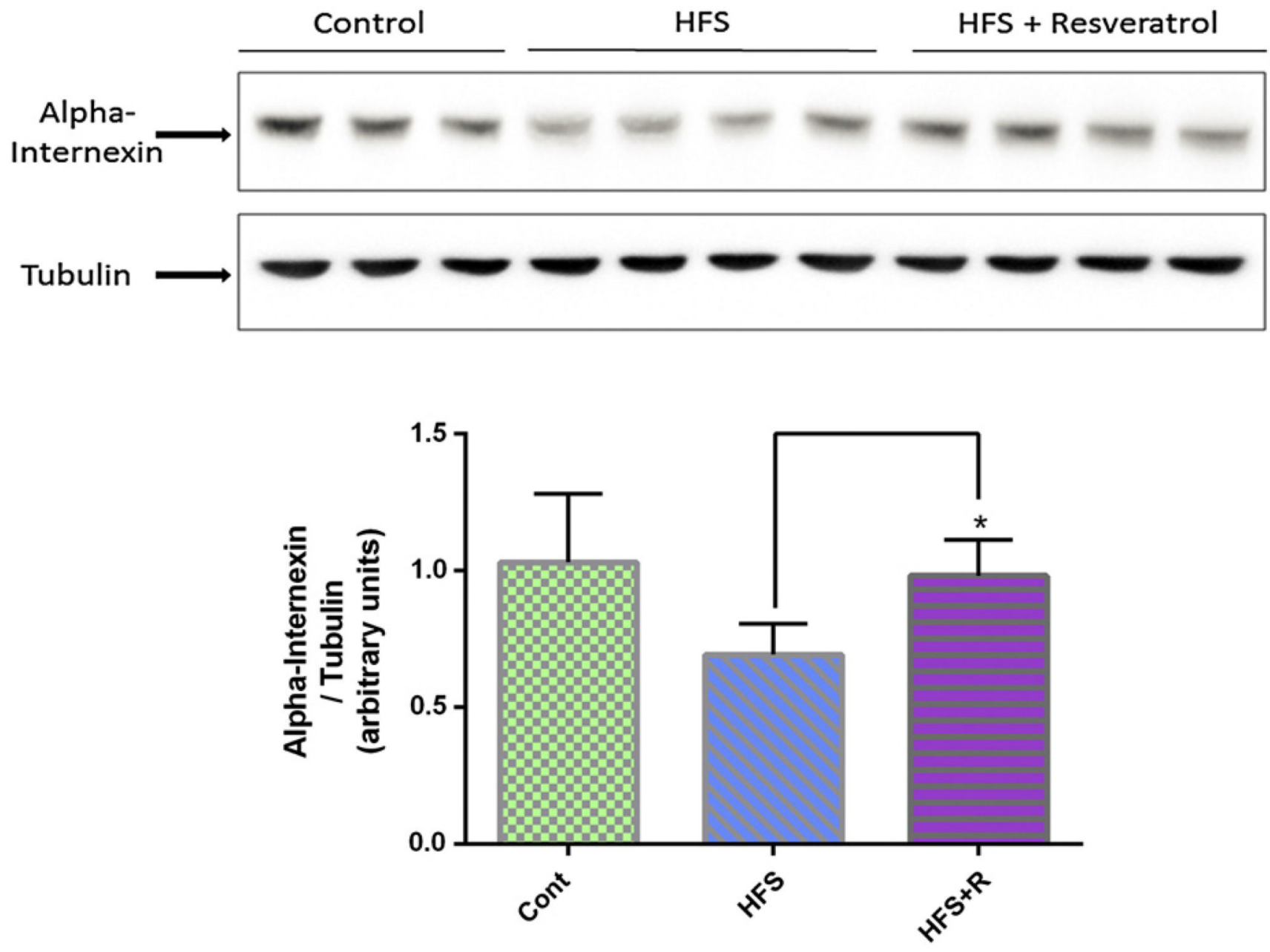

\section{Experimental Group}

Fig. 5.

Western blot validation of alpha-internexin levels across each group normalized against tubulin $(* P \leq 05)$. 

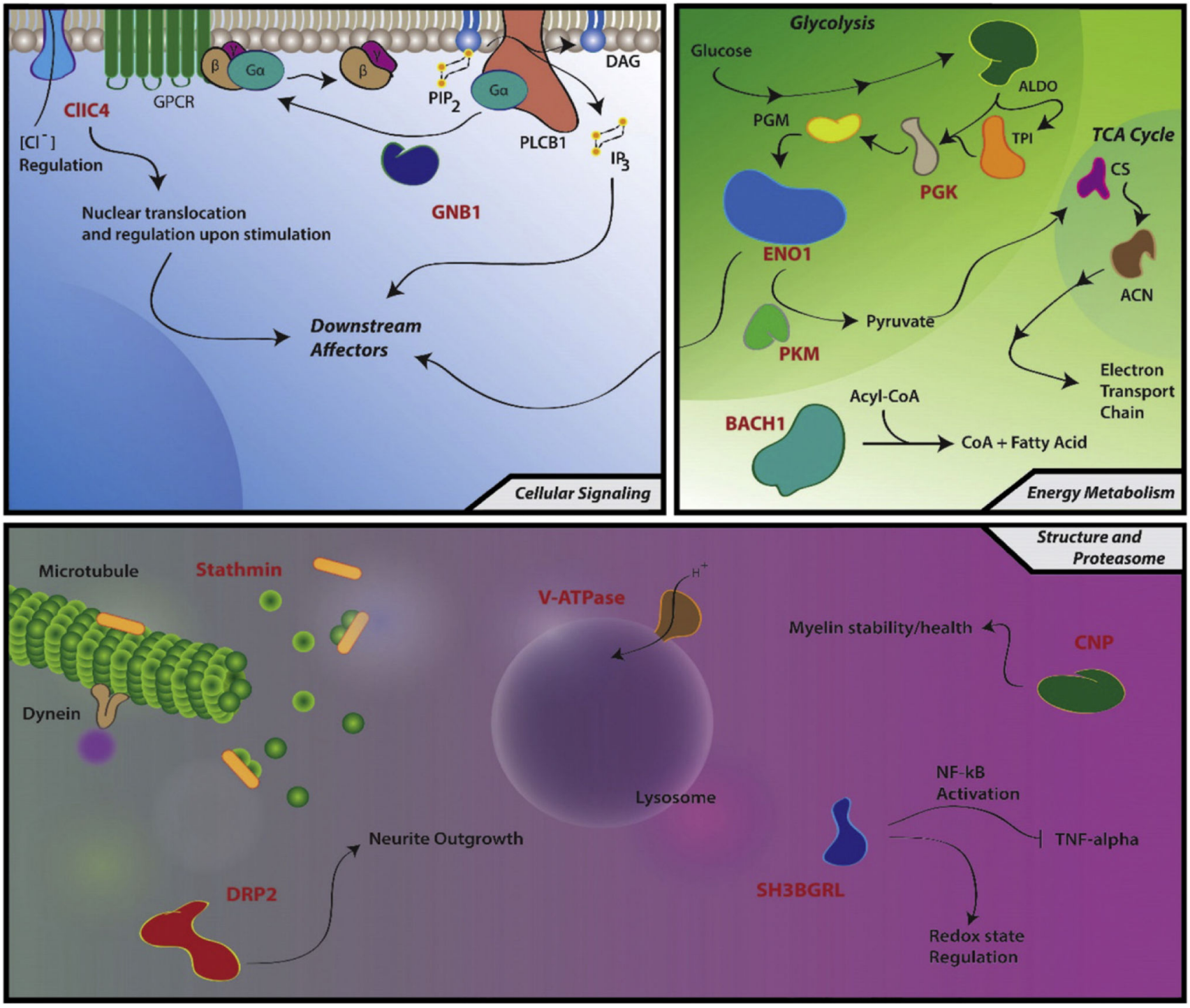

Fig. 6 .

The above figure outlines the proteins and canonical functions of those found to be of differentially expressed in the present study. Proteins identified within this study are labelled in red. 


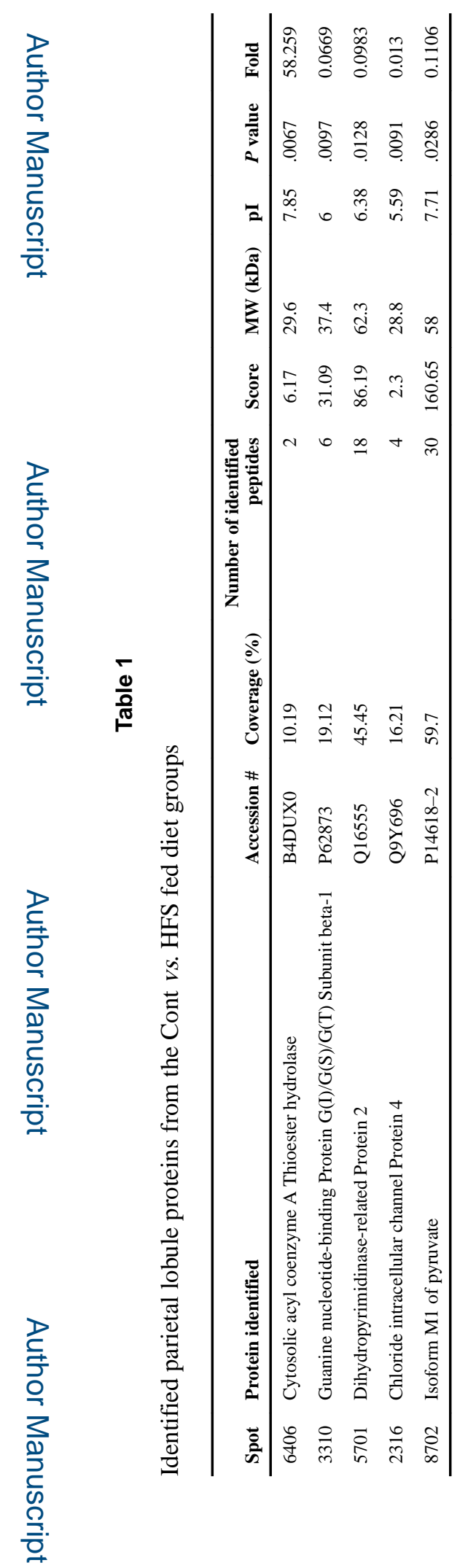




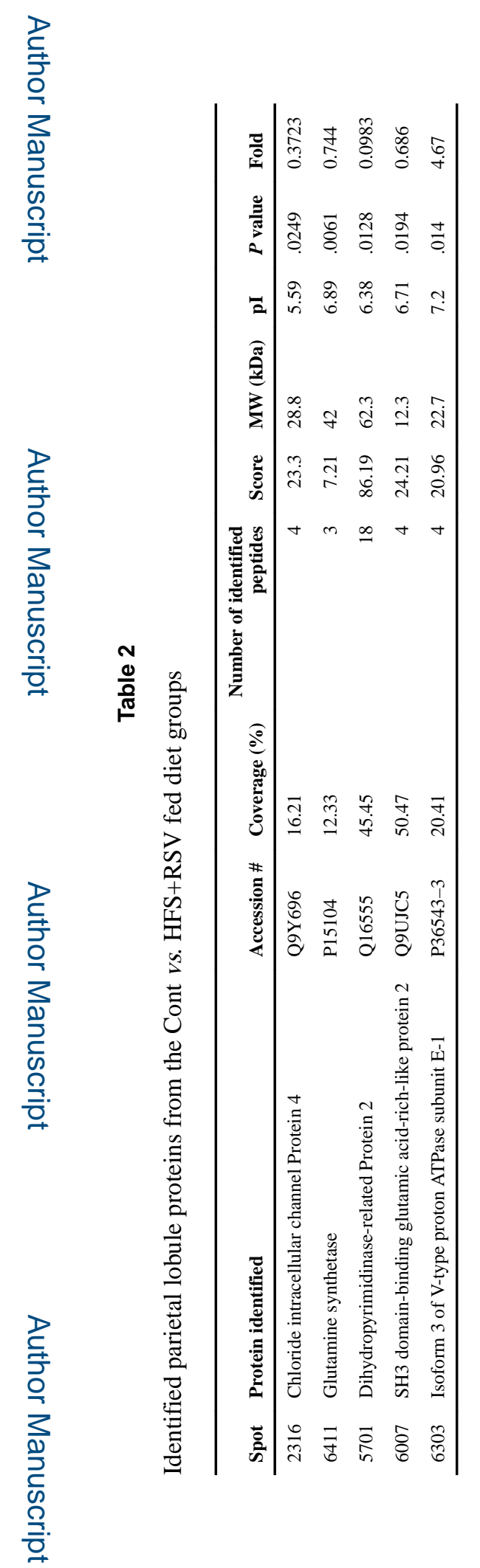

J Nutr Biochem. Author manuscript; available in PMC 2017 November 01. 


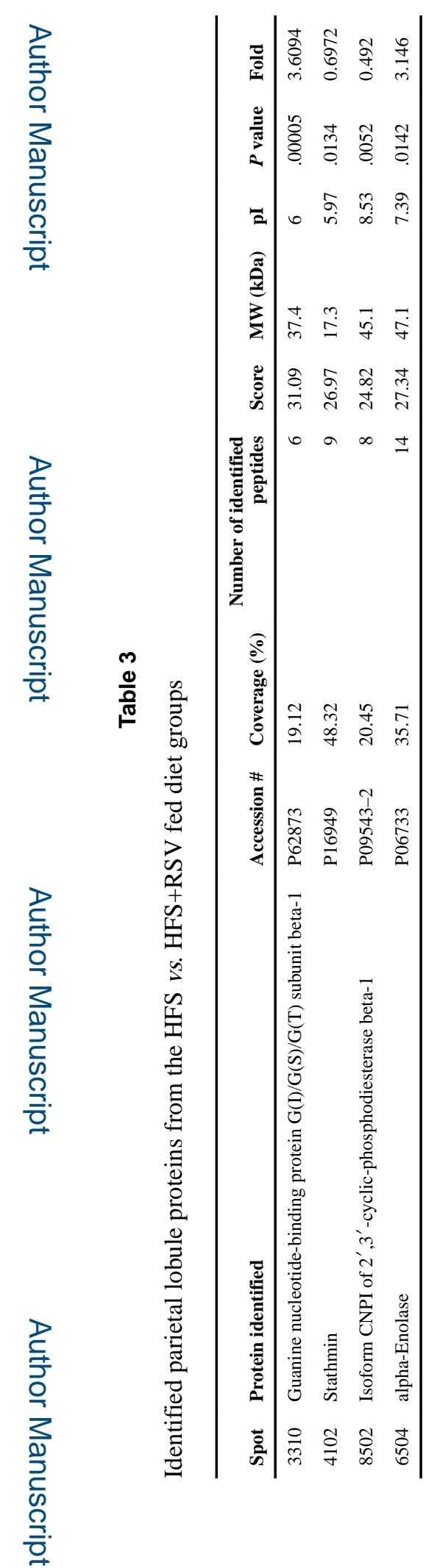

